\title{
The Structure and Fragmentation of $\mathrm{B}_{n}(n \geq 3)$ Ions in Peptide Spectra
}

\author{
Talat Yalcin, Imre G. Csizmadia, Michael R. Peterson, and \\ Alex G. Harrison \\ Department of Chemistry, University of Toronto, Toronto, Ontario, Canada
}

\begin{abstract}
The unimolecular and low energy collision-induced fragmentation reactions of the $\mathrm{MH}^{+}$ions of $\mathrm{N}$-acetyl-tri-alanine, $\mathrm{N}$-acetyl-tri-alanine methyl ester, $\mathrm{N}$-acetyl-tetra-alanine, tetra-alanine, penta-alanine, hexa-glycine, and Leu-enkephalin have been studied with a particular emphasis on the formation and fragmentation of $\mathrm{B}_{n}(n=3,4,5)$ ions. In addition, the metastable ion fragmentation reactions of protonated tetra-glycine, penta-glycine, and Leu-enkephalin amide have been studied. $\mathrm{B}_{n}$ ions are prominent stable species in all spectra. The $\mathrm{B}_{n}$ ions fragment, in part, by elimination of $\mathrm{CO}$ to form $\mathrm{A}_{n}$ ions; this reaction occurs on the metastable ion time scale with a substantial release of kinetic energy $\left(T_{1 / 2}=0.3-0.5 \mathrm{eV}\right)$ that indicates that a stable configuration of the $B_{n}$ ion fragments by way of a reacting configuration that is higher in energy than the fragmentation products, $\mathrm{A}_{n}+\mathrm{CO}$. $\mathrm{Ab}$ initio calculations strongly suggest that the stable configuration of the $B_{3}$ and $B_{4}$ ions is a protonated oxazolone formed by interaction of the developing charge with the next-nearest carbonyl group as $\mathrm{HX}$ is lost from the protonated species $\mathrm{H}-\left(\mathrm{Yyy}_{n}\right)_{n}-\mathrm{X} \cdot \mathrm{H}^{+}$. The higher $\mathrm{B}_{n}$ ions also fragment, in part, to form the next-lower $B$ ion, presumably in its stable protonated oxazolone form. This reaction is rationalized in terms of the three-dimensional structure of the $B_{n}$ ions and it is proposed that the neutral eliminated is an $\alpha$-lactam. (J Am Soc Mass Spectrom 1996, 7, 233-242)
\end{abstract}

$\mathrm{P}$ rotonated $\alpha$-amino acids and derivatives such as methyl esters and amides do not form stable acylium ions $\left[\mathrm{RCH}\left(\mathrm{NH}_{2}\right) \mathrm{CO}\right]^{+}$on fragmentation; rather, the incipient acylium ion eliminates $\mathrm{CO}$ exothermically to form the stable immonium ion $\mathrm{RCH}=\mathrm{NH}_{2}^{+}[1-7]$. By contrast, the mass spectra of protonated peptides [both the fast-atom bombardment (FAB) ionization mass spectra and the collision-induced dissociation (CID) mass spectra] frequently show abundant formation of $\mathrm{B}_{n}$ ions (Scheme I), which usually have been assumed to be acylium ions [8-13]. The $B_{n}$ series of ions that are observed often provide substantial sequence information for the peptide.

In our laboratory we have addressed the question of why the B ions derived from peptides, which are nominally acylium ions, are stable whereas the acylium ions derived from $\alpha$-amino acids are not stable. We recently reported a study [7] of the formation and fragmentation of the $B$ ions derived by loss of $\mathrm{HX}$ from protonated dipeptide derivatives $\mathrm{H}_{2} \mathrm{NCH}\left(\mathrm{R}^{\prime}\right) \mathrm{C}(=\mathrm{O}) \mathrm{NHCH}(\mathrm{R}) \mathrm{C}(=\mathrm{O}) \mathrm{X} \cdot \mathrm{H}^{+}$ and from protonated $\mathrm{N}$-acyl peptide derivatives $\mathrm{R}^{\prime \prime} \mathrm{C}(=\mathrm{O}) \mathrm{NHCH}(\mathrm{R}) \mathrm{C}(=\mathrm{O}) \mathrm{X} \cdot \mathrm{H}^{+}$. The $N$-acyl peptide derivatives and the dipeptide derivatives showed a very similar behavior in that $\mathrm{HX}$ was lost from the

Address reprint requests to Alex G. Harrison, Department of Chemistry, University of Toronto, Toronto, Ontario M5S 1A1, Canada.

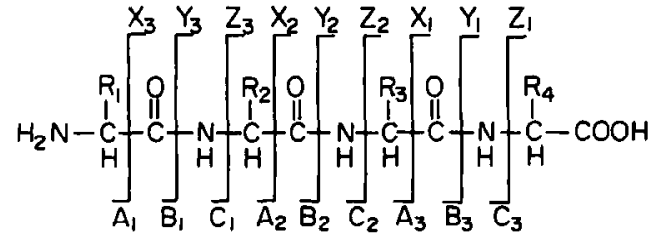<smiles>[R6]C(N)C(=O)NC([R6])C(=O)O[3H]</smiles><smiles>[Y2]C(NC(=O)C([R9])([Y])[18F])C(=O)O</smiles>

Scheme I

protonated species to form stable $B_{2}$ ions. ${ }^{*}$ These $B_{2}$ ions fragmented, in part, by elimination of $\mathrm{CO}$ and showed flat-topped metastable peaks that gave kinetic energy releases $\left(T_{1 / 2}\right)$ in the $0.3-0.5-\mathrm{eV}$ range. These large kinetic energy releases indicate [14] that a stable configuration (S) of the $B_{2}$ ions fragments by way of a

\footnotetext{
- In the usual nomenclature for peptide fragment ions $[8,11,12]$ the ions derived from the dipeptide derivatives are $B_{2}$ ions whereas the ions derived from the $N$-acyl peptide derivatives are $B_{1}$ ions because they contain only one amino acid residue. However, because of their similarity in behavior we will term both as $B_{2}$ ions. Similarly, we will use the term $B_{n}$ for $B$ ions that contain $n$ amino acid residues as well as for $B$ ions that contain $(n-1)$ amino acid residues and an $N$-acyl group. As will be shown in the present work, the chemistry of B ions is determined not by the number of amino acid residues that they contain, but by the number of carbonyl groups.
} 


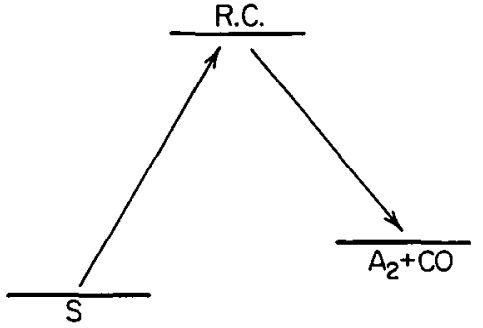

Figure 1. Potential energy profile for reaction that leads to a large kinetic energy release.

reacting configuration ( $\mathrm{RC}$ ) that is higher in energy than the products as shown schematically in Figure 1. In such cases partitioning of some of the final fragmentation exothermicity into kinetic energy of the separating fragments results in relatively large kinetic energy releases.

From a comparison of the fragmentation behavior of protonated 2-phenyl-5-oxazolone (a, Scheme II) and the $B_{2}$ ion derived from protonated $\mathrm{C}_{6} \mathrm{H}_{5}-\mathrm{C}(=\mathrm{O})$ Gly-Gly-OH, it was concluded that the stable configuration for the $B_{2}$ ion is a protonated oxazolone $(b$, Scheme II). This conclusion was supported by ab initio calculations on the simplest $\mathrm{B}_{2}$ ion, nominally $\left[\mathrm{HC}(=\mathrm{O}) \mathrm{NHCH}_{2} \mathrm{CO}\right]^{+}$, which showed that the lowest energy structure was the protonated oxazolone. The acyclic acylium isomer was found to be $1.49 \mathrm{eV}$ higher in energy than the protonated oxazolone and $0.88 \mathrm{eV}$ higher in energy than the fragmentation products $\mathrm{HC}(=\mathrm{O}) \mathrm{NH}^{+}=\mathrm{CH}_{2}+\mathrm{CO}$, which are consistent with the kinetic energy releases measured.

The present paper extends these studies to $B_{3}$ and $B_{4}$ ions in the spectra of peptides and the corresponding ions in the spectra of $N$-acyl peptides. The experimental work has involved CID studies and metastable ion studies, which include kinetic energy release measurements. In addition, we have carried out ab initio calculations to determine the energy minima for $B_{3}$ and $B_{4}$ ions as well as the energy of some of the fragmentation products. The results to be presented will show that the stable configuration of $B_{3}$ and $B_{4}$ ions and, presumably, larger $B$ ions, are best described as substituted protonated oxazolones.

\section{Experimental}

All experiments were carried out by using a VG Analytical (Manchester, UK) ZAB-2FQ mass spectrometer that has been described in detail previously [15].<smiles>CC(C)(C)C1=NCC(=O)O1</smiles>
$\stackrel{a}{\sim}$<smiles>[R][C+]1NC([R])C(=O)O1</smiles>

$\stackrel{b}{\sim}$
Scheme II
Briefly, the instrument is a reversed-geometry (BE) double-focusing mass spectrometer with a third stage that consists of a deceleration lens system, a radiofrequency (rf)-only quadrupole collision cell (q), and a quadrupole mass analyzer $(\mathrm{Q})$. The ions studied were prepared by fast-atom bombardment (FAB) by using an $\mathrm{Ar}$ or Xe atom beam of 7-8-keV energy with the appropriate sample dissolved in a matrix that consists of thioglycerol/2,2'-dithiodiethanol (1:1) saturated with oxalic acid. The use of $\mathrm{Xe}$ gave more intense ion signals for higher molecular weight peptides such as Leu-enkephalin and Leu-enkephalin amide. The ion source was operated at room temperature.

In a limited number of cases the ions of interest also were prepared by $\mathrm{CH}_{4}$ chemical ionization $(\mathrm{CI})$. In these studies the electron ionization-chemical ionization source was operated in the CI mode with an ionizing electron energy of $100 \mathrm{eV}$ and a source temperature of $250{ }^{\circ} \mathrm{C}$. The peptides were introduced into the ion source either by way of a conventional heated solids probe or by way of a direct exposure probe. The latter consisted of a small loop of platinum wire that could be heated by passing an electrical current through it. A solution of the peptide was evaporated to dryness on the loop, which then was introduced directly into the $\mathrm{CI}$ reagent plasma. The $\mathrm{CH}_{4}$ reagent gas was introduced by way of the $\mathrm{CI}$ reagent gas inlet to a source pressure estimated to be $\sim 0.3$ torr.

To obtain relative intensities of fragment ions formed on the metastable ion time scale, the precursor ion of interest was mass-selected by the BE doublefocusing mass spectrometer at 6-keV ion energy, decelerated to $20-40-\mathrm{eV}$ kinetic energy, and introduced into the rf-only quadrupole cell in the absence of collision gas. Low energy collision-induced dissociation (CID) studies were carried out in the same fashion but with the addition of $\mathrm{N}_{2}$ at an indicated pressure of $2-3 \times$ $10^{-7}$ torr to the quadrupole collision cell. In the CID experiments the incident ion energy was typically varied from 2 to $45 \mathrm{eV}$ (laboratory scale).

Kinetic energy releases associated with the unimolecular fragmentation reactions were determined by the mass-analyzed ion kinetic energy spectrometry technique [16]. In this technique the ion of interest was mass-selected by the magnetic sector at $6-\mathrm{keV}$ ion energy and the products of unimolecular fragmentation reactions in the drift region between the magnetic and electric sectors were identified according to their kinetic energy by scanning the electric sector. The kinetic energy releases were determined from the peak widths at half-height after correction for the inherent energy spread of the ion beam according to the relation [14]

$$
w_{\text {corr }}=\left(w_{\text {met }}^{2}-w_{\text {mb }}^{2}\right)^{1 / 2}
$$

where $w_{\text {met }}$ is the measured width of the metastable ion and $w_{\mathrm{mb}}$ is the width of the parent ion main beam. The corrected half-widths were converted to $T_{1 / 2}$ val- 
Table 1. Metastable fragmentation of $\mathrm{MH}^{+}$ions

\begin{tabular}{|c|c|c|c|c|c|c|c|}
\hline \multirow[b]{2}{*}{ M } & \multicolumn{7}{|c|}{ Fragment ion ( $\%$ of base peak) } \\
\hline & $B_{6}$ & $B_{5}$ & $\mathbf{B}_{4}$ & $\mathrm{~B}_{3}$ & $Y_{4}$ & $Y_{3}$ & $Y_{2}$ \\
\hline$\overline{\mathrm{Ac}}-(\mathrm{Ala})_{3}-\mathrm{OH}$ & & & 44 & 100 & & & 65 \\
\hline $\mathrm{Ac}-(\mathrm{Ala})_{4}-\mathrm{OMe}^{\mathrm{a}}$ & & & 68 & 99 & & & 100 \\
\hline $\mathrm{H}-(\mathrm{Ala})_{4}-\mathrm{OH}$ & & & 14 & 52 & & & 100 \\
\hline $\mathrm{Ac}-(\mathrm{Ala})_{4}-\mathrm{OH}$ & & 37 & 100 & & & 10 & 3 \\
\hline $\mathrm{H}-(\mathrm{Ala})_{5}-\mathrm{OH}$ & & 34 & 100 & 22 & & 26 & 8 \\
\hline $\mathrm{H}-(\mathrm{Gly})_{4}-\mathrm{OH}$ & & & 77 & 32 & & & 100 \\
\hline $\mathrm{H}-(\mathrm{Gly})_{5}-\mathrm{OH}$ & & 92 & 100 & 24 & & 78 & 32 \\
\hline $\mathrm{H}-(\mathrm{Gly})_{6}-\mathrm{OH}$ & 59 & 100 & 62 & & 29 & 27 & \\
\hline Leu-enkeph ${ }^{b}$ & & 20 & 100 & 13 & 4 & 14 & 12 \\
\hline Leu-enkeph-NH $\mathrm{N}_{2}$ & & 100 & 13 & & & & \\
\hline
\end{tabular}

iAlso $Y_{1}=9$

Leu-Enkeph $=\mathrm{H}-$ Tyr-Gly-Gly-Phe-Leu-OH.

ues by using the equation developed [16] for electric sector scans. Because of the low intensities of the metastable ion peaks, the kinetic energy release measurements were made under conditions of low energy resolution. It is for this reason that the correction has been applied to the "flat-topped" metastable peaks for the $\mathrm{B}_{n} \rightarrow \mathrm{A}_{n}$ fragmentation; the $T_{1 / 2}$ values were $\sim 0.05 \mathrm{eV}$ larger without this correction.

The compounds used were obtained from Aldrich Chemical Co. (Milwaukee, WI), Sigma Chemical Co. (St. Louis, MO), or Bachem Biosciences, Inc. (King of Prussia, PA). In some cases the $N$-acetyl derivatives were prepared by reaction of the appropriate precursor that contains the free amine end with acetic anhydride in $t$-butanol. A portion of this reaction mixture was then added to the matrix used for FAB without isolation of the $N$-acetyl derivative.

\section{Results and Discussion}

The peptides that were studied were $\mathrm{Ac}-(\mathrm{Ala})_{3}-\mathrm{OH}$, $\mathrm{H}-(\mathrm{Ala})_{4}-\mathrm{OH}, \mathrm{Ac}-(\mathrm{Ala})_{4}-\mathrm{OH}, \mathrm{H}-(\mathrm{Ala})_{5}-\mathrm{OH}, \mathrm{H}-(\mathrm{Gly})_{4}^{-}$

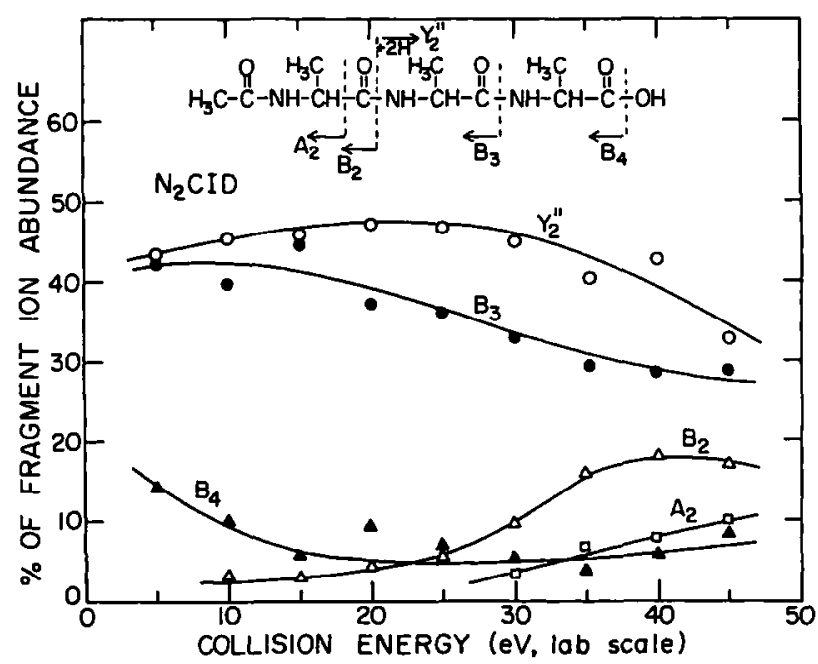

Figure 2. Breakdown graph for protonated Ac-(Ala $)_{3}-\mathrm{OH}$.

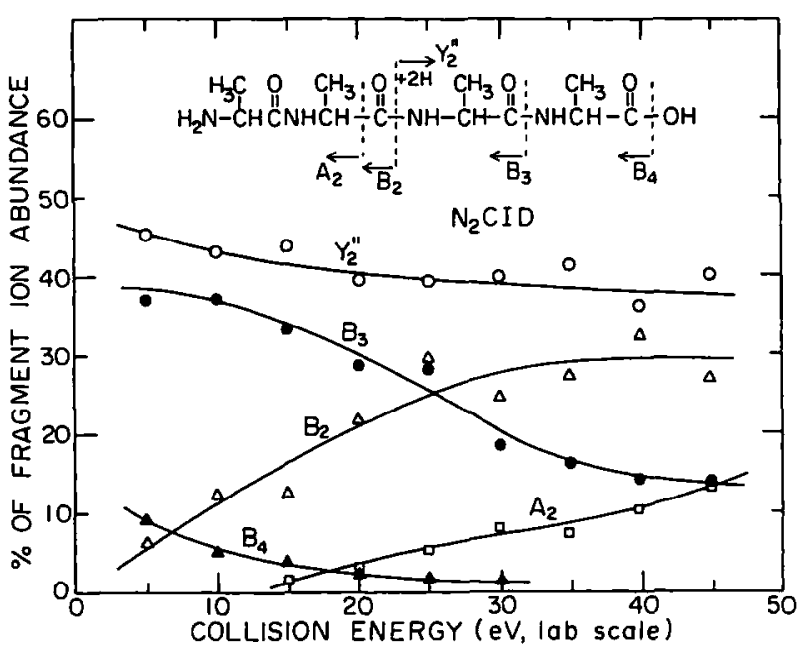

Figure 3. Breakdown graph for protonated $\mathrm{H}-(\mathrm{Ala})_{4}-\mathrm{OH}$.

$\mathrm{OH}, \mathrm{H}-(\mathrm{Gly})_{5}-\mathrm{OH}, \mathrm{H}-(\mathrm{Gly})_{6}-\mathrm{OH}, \mathrm{H}-\mathrm{Tyr}-\mathrm{Gly}-\mathrm{Gly}-\mathrm{Phe}-$ Leu-OH (Leu-enkephalin), and H-Tyr-Gly-Gly-PheLeu- $\mathrm{NH}_{2}$ (Leu-enkephalin amide). Table 1 records the metastable ion mass spectra observed for fragmentation of the protonated species $\mathrm{MH}^{+}$, of each peptide. The metastable ion mass spectrum recorded for protonated Leu-enkephalin is in good agreement with that reported by Alexander and Boyd [17]. Clearly, B ions are prominent species in the metastable mass spectra of all the protonated peptides, which indicated their stability. It should be noted, however, that no $B_{1}$ ions are observed for the peptides because they would have an acylium structure, and the earlier work on protonated amino acids $[3,7]$ indicates that such acylium ions are unstable. In general, the most abundant $B$ ion in the metastable ion spectra is that which results from loss of the C-terminus amino acid as a neutral (or, for Leu-enkephalin amide, loss of the $C$-terminus amide group as ammonia). Stable B ions also are prominent product ions in the CID mass spectra of the protonated peptides. Figures 2-7 present the low energy CID mass spectra of the $\mathrm{MH}^{+}$ions of six peptides in the 


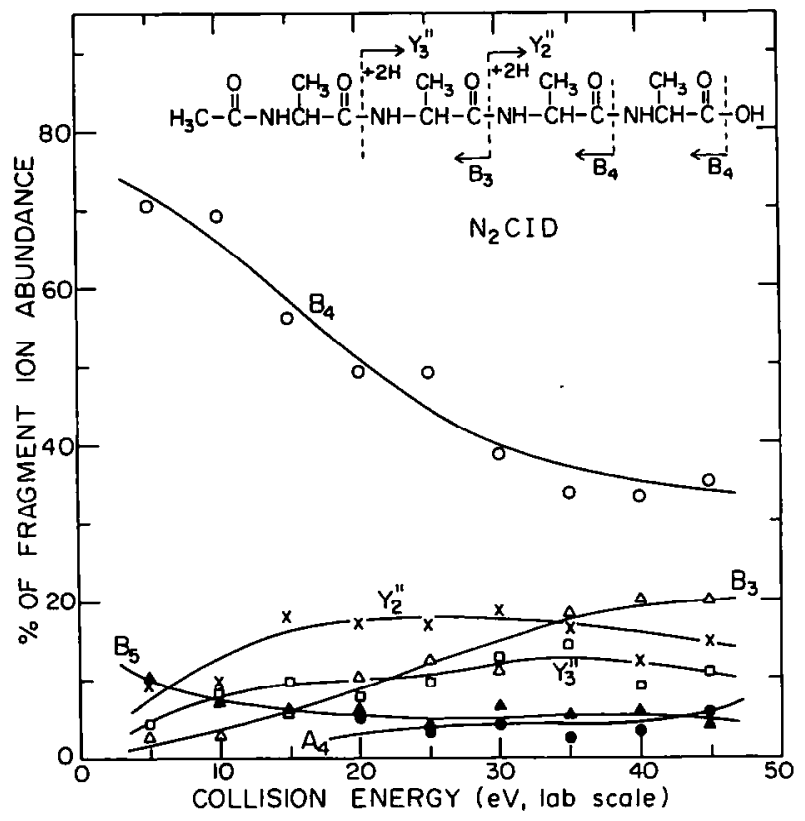

Figure 4. Breakdown graph for protonated $\mathrm{Ac}-(\mathrm{Ala})_{4}-\mathrm{OH}$.

form of breakdown graphs that express the percent fragment ion abundance as a function of the collision energy (laboratory scale).

In a number of cases the $B_{4}$ and $B_{3}$ ions were of sufficient intensities in the FAB mass spectra that their unimolecular and collision-induced fragmentation reactions could be studied. Tables 2 and 3 record the relative intensities of the product ions observed in the unimolecular (metastable ion) fragmentation of a selection of $B_{3}$ and $B_{4}$ ions. The metastable ion spectrum observed for the $B_{3}$ ion derived from Leu-enkephalin is in good agreement with that reported earlier [17]. Two major metastable ion fragmentation pathways, in general, are observed: elimination of $\mathrm{CO}$ to form an A ion (reaction 2) and fragmentation to form the next-

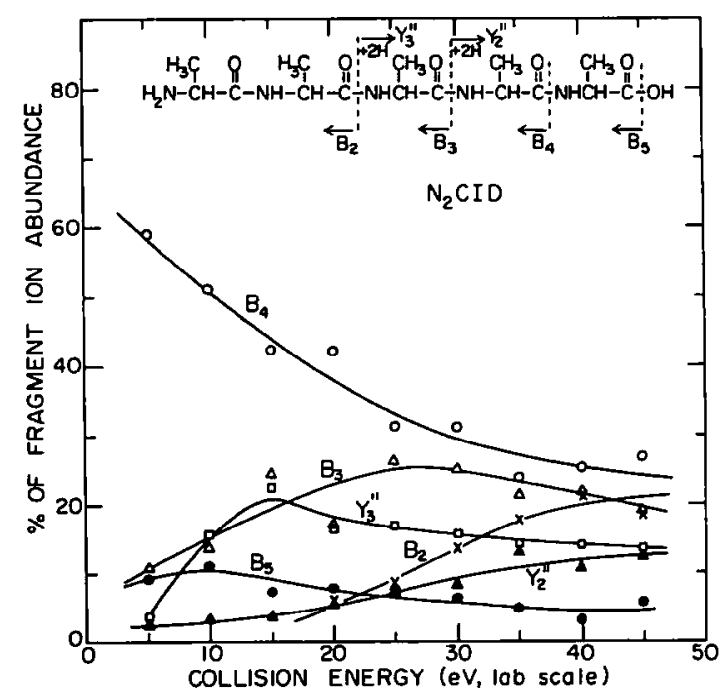

Figure 5. Breakdown graph for protonated $\mathrm{H}-(\mathrm{Ala})_{5}-\mathrm{OH}$.

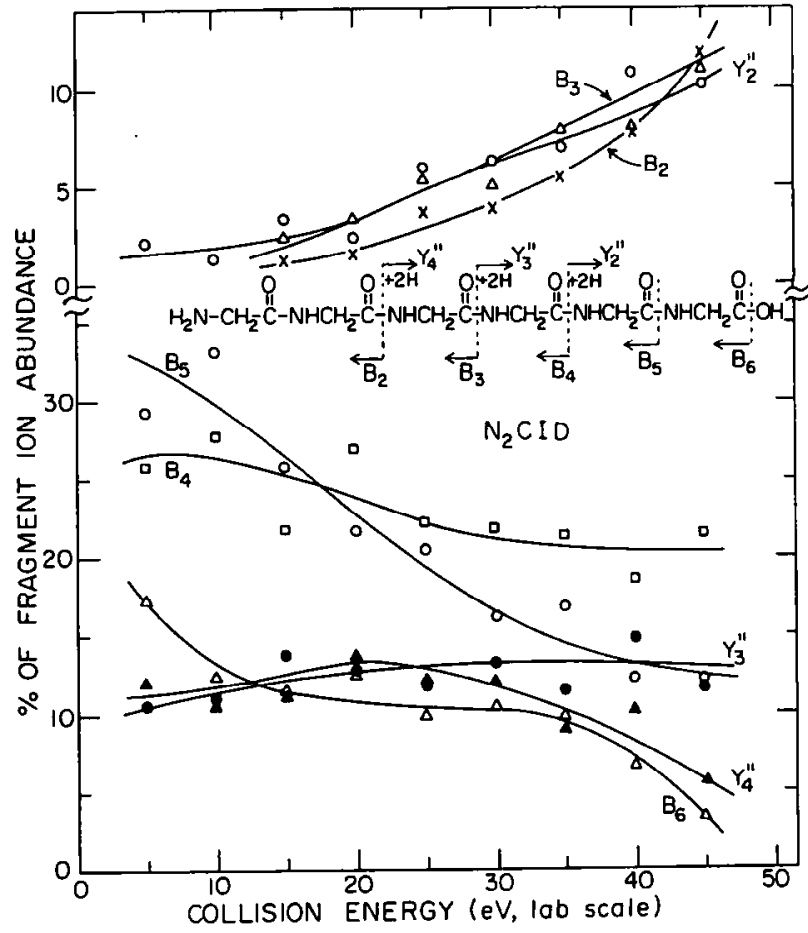

Figure 6. Breakdown graph for protonated $\mathrm{H}-(\mathrm{Gly})_{6}-\mathrm{OH}$.

lower B ion (reaction 3):

$$
\begin{gathered}
\mathrm{B}_{n} \rightarrow \mathrm{A}_{n}+\mathrm{CO} \\
\mathrm{B}_{n} \rightarrow \mathrm{B}_{n-1}+[\mathrm{NHCH}(\mathrm{R}) \mathrm{CO}]
\end{gathered}
$$

Unimolecular fragmentation of the $B_{3}$ ions derived

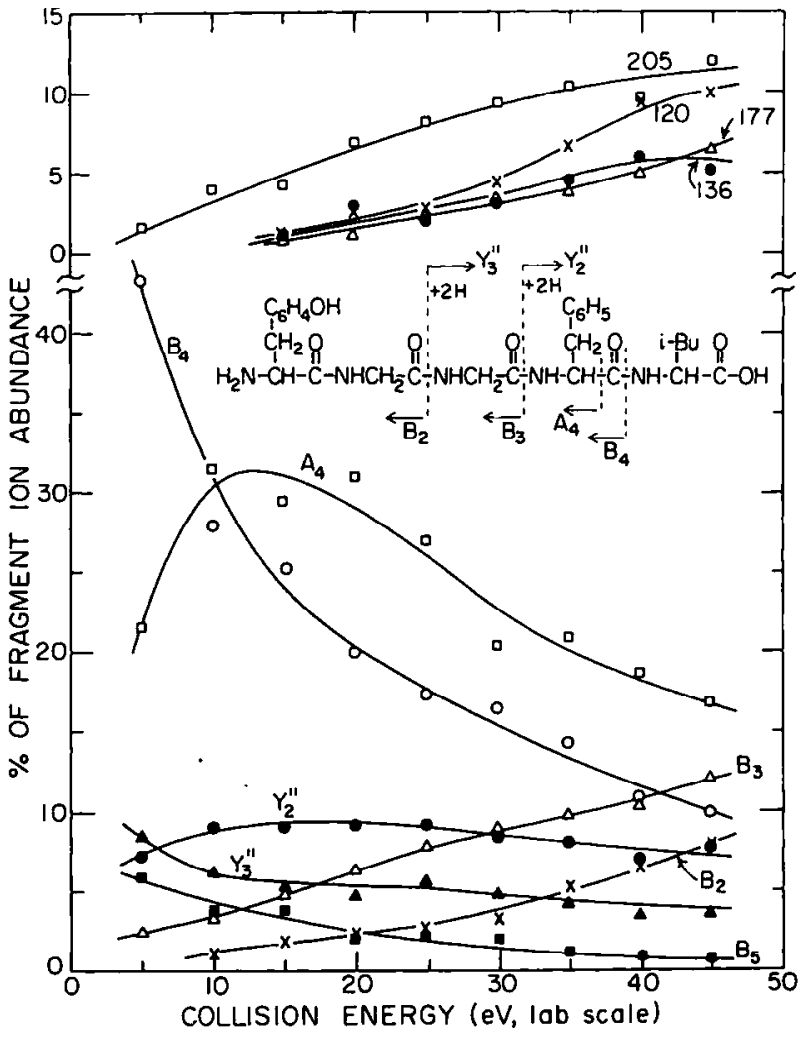

Figure 7. Breakdown graph for protonated Leu-enkephalin. 
Table 2. Metastable fragmentation of $B_{3}$ ions

\begin{tabular}{|c|c|c|c|}
\hline \multirow[b]{2}{*}{ Source } & \multicolumn{3}{|c|}{$\%$ of Base peak $\left(T_{1 / 2}, e V\right)$} \\
\hline & $A_{3}$ & $\mathrm{~B}_{2}$ & $A_{1}$ \\
\hline $\mathrm{Ac}-(\mathrm{Ala})_{3}-\mathrm{OMe}$ & $100(0.46)$ & & \\
\hline $\mathrm{Ac}-(\mathrm{Ala})_{4}-\mathrm{OH}$ & $100(0.46)$ & $4(0.083)$ & \\
\hline $\mathrm{H}-(\mathrm{Ala})_{5}-\mathrm{OH}^{\mathrm{a}}$ & $81(0.50)$ & $71(0.097)$ & \\
\hline Leu-enkeph & $11(0.45)$ & $100(0.092)$ & 9 \\
\hline
\end{tabular}

${ }^{\mathrm{a}}$ Also $-\left(\mathrm{NH}_{3}+\mathrm{CO}\right)-100$.

from penta-alanine and from Leu-enkephalin by loss of $\left(\mathrm{CO}+\mathrm{NH}_{3}\right)$ also is observed. Reaction 2 also is observed in the fragmentation of $B_{2}$ ions [7]; however, reaction 3 , which has been observed earlier $[17,18]$ for larger $B$ ions, is not observed for $B_{2}$ ions.

Tables 2 and 3 also report the kinetic energy releases $\left(T_{1 / 2}\right)$ measured, where possible, for fragmentation reactions 2 and 3 that occur on the metastable ion time scale. In addition, the $B_{5}$ ion observed in the $F A B$ mass spectrum of Leu-enkephalin amide showed metastable peaks for reactions 2 and 3 , with a kinetic energy release for reaction 2 of $0.28 \mathrm{eV}$. Thus, reaction 2 occurs for $B_{3}, B_{4}$, and $B_{5}$ ions with substantial release of kinetic energy $\left(T_{1 / 2}=0.3-0.5 \mathrm{eV}\right)$, in agreement with the results reported earlier [7] for $B_{2}$ ions. These results indicate a potential energy surface for elimination of $\mathrm{CO}$ from $\mathrm{B}_{n}(n \geq 3)$ ions similar to that shown schematically in Figure 1 . We shall return later to the question of the stable structure and the reacting configuration involved for these higher $B$ ions. The larger $B$ ions also fragment to a considerable extent by elimination of $[\mathrm{HNCH}(\mathrm{R}) \mathrm{CO}]$ (reaction 3 ) to form the nextlower $\mathrm{B}$ ion. This is evident from the metastable ion data of Tables 2 and 3 and from the low energy CID data for the $B_{3}$ and $B_{4}$ ions derived from Leu-enkephalin, which are presented in Figures 8 and 9 . Fragmentation of the $B_{5}$ ion from Leu-enkephalin amide by reaction 3 occurs with a kinetic energy release $\left(T_{1 / 2}\right)$ of $0.087 \mathrm{eV}$. The mechanism of reaction 3, which involves a smaller kinetic energy release $\left(T_{1 / 2}=0.08-0.09 \mathrm{eV}\right)$, will be discussed subsequently in light of the theoretical calculations.

\section{Theoretical Calculations}

In our earlier work [7] we reported ab initio calculations on the structure of the simplest possible $\mathrm{B}$ ion, nominally $\mathrm{HC}(=\mathrm{O}) \mathrm{NHCH}_{2} \mathrm{CO}^{+}$. In the present work we have extended these calculations to the larger $\mathrm{B}$

Table 3. Metastable fragmentation of $B_{4}$ ions

\begin{tabular}{lccc}
\hline & \multicolumn{3}{c}{$\%$ of Base peak $\left(T_{1 / 2}, \mathrm{eV}\right)$} \\
Source & $\mathrm{A}_{4}$ & $\mathrm{~B}_{3}$ & $\mathrm{~B}_{2}$ \\
\hline \hline Ac-(Ala) $)_{3}-\mathrm{OMe}$ & $100(0.43)$ & 6 & \\
Ac-(Ala $)_{4}-\mathrm{OH}$ & $100(0.45)$ & 8 & \\
$\mathrm{H}-(\mathrm{Ala})_{5}-\mathrm{OH}$ & $100(0.41)$ & $38(0.078)$ & 7 \\
Leu-enkeph & $100(0.32)$ & 7 & \\
\hline
\end{tabular}

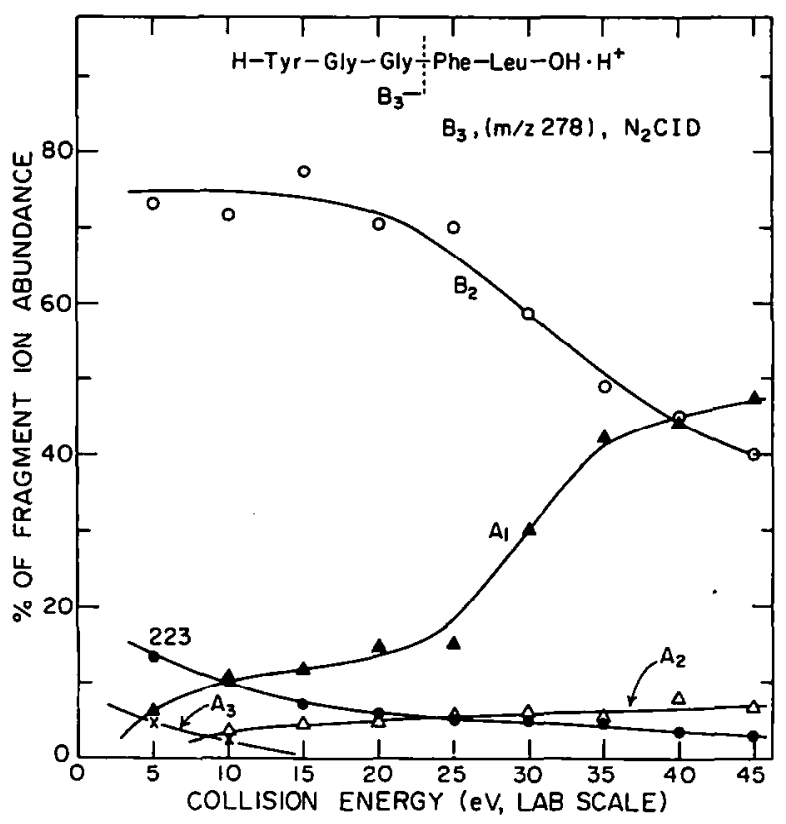

Figure 8. Breakdown graph for the $B_{3}$ ion derived from Leu-enkephalin.

ions, nominally<smiles></smiles>

and

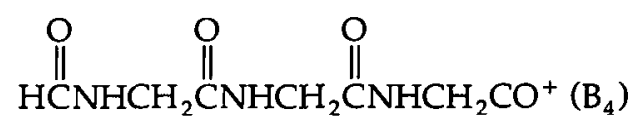

as well as some anticipated fragmentation products.

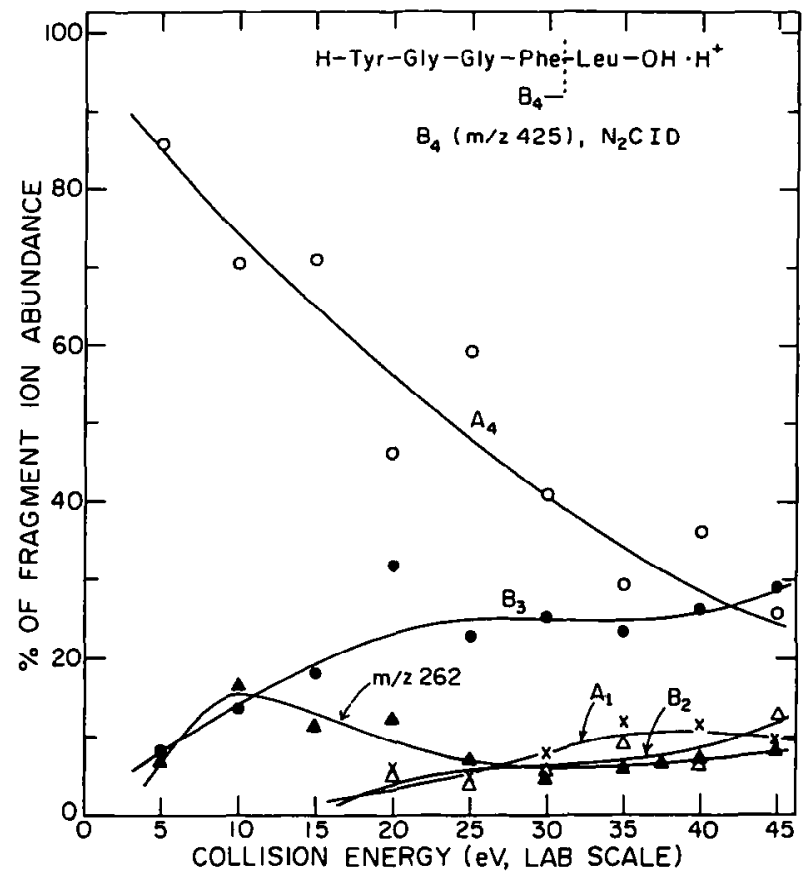

Figure 9. Breakdown graph for the $B_{4}$ ion derived from Leu-enkephalin. 
The calculations were carried out by using the Gaussian 92 series of programs [19] that employ restricted Hartree-Fock formalism. Fully optimized geometries were calculated initially at the $3-21 \mathrm{G}$ split valence basis set [20] level of theory. These geometrical parameters subsequently were used for input to calculations of the fully relaxed geometries, total energies, and harmonic frequencies at the HF/6-31G* level of theory, except for the $B_{4}$ ion where calculations were terminated at the 3-21G level. Figures 10 to 14 show the structures of the species for which calculations were performed whereas Table 4 lists the total energies calculated at the 3-21G and $6-31 \mathrm{G}^{*}$ levels of theory. We have included, for comparison, in Figure 10 and in Table 4 the results obtained for the $\mathrm{B}_{2}$ ion, nominally $\mathrm{HC}(=\mathrm{O}) \mathrm{NHCH}_{2} \mathrm{CO}^{+}$, at the $6-31 \mathrm{G}^{*}$ level. In our earlier work [7] results obtained for the $B_{2}$ ion at the 6-31G** level were reported.

With full geometry optimization for the $B_{3}$ and $B_{4}$ ions the energy minima were found to be the cyclic structures $d$ and $e$. As was found for the $B_{2}$ ion system [7], no stable acyclic structures could be found for $B_{3}$ and $B_{4}$. By holding torsional angles constant to prevent cyclization, acyclic structures were found, but all resulted in one imaginary frequency, which indicated that the structures corresponded to saddle points not stable structures on the potential energy hypersurface.

The calculations for the $B_{3}$ and $B_{4}$ ions are in agreement with the earlier [7] results for the $B_{2}$ ion in that on formation they undergo cyclization to form a protonated oxazolone by interaction with the next-nearest carbonyl function (Scheme III). We also have calculated the structure (Figure 13)

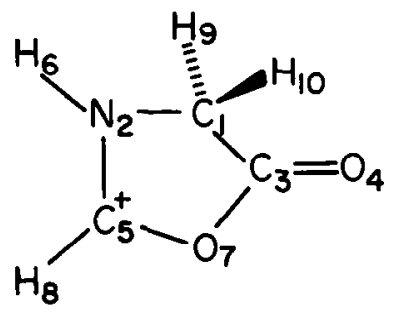

$\mathrm{C}_{3} \mathrm{C}_{1} \mathrm{~N}_{2}=100.4273$

$\mathrm{O}_{4} \mathrm{C}_{3} \mathrm{C}_{1}=132.8609$

$\mathrm{C}_{5} \mathrm{~N}_{2} \mathrm{C}_{1}=110.6367$

$\mathrm{H}_{6} \mathrm{~N}_{2} \mathrm{C}_{3}=124.0893$

$\mathrm{O}_{7} \mathrm{C}_{5} \mathrm{~N}_{2}=114.6932$

$\mathrm{H}_{8} \mathrm{C}_{5} \mathrm{~N}_{2}=125.6491$

$\mathrm{H}_{9} \mathrm{C}_{1} \mathrm{~N}_{2}=111.6957$

$\mathrm{H}_{10} \mathrm{C}_{1} \mathrm{~N}_{2}=111.6957$

$r_{101}=1.0813$

$r_{73}=1.4286$
$\mathrm{C}_{5} \mathrm{~N}_{2} \mathrm{C}_{1} \mathrm{C}_{3}=0.0$

$\mathrm{O}_{4} \mathrm{C}_{3} \mathrm{C}_{1} \mathrm{~N}_{2}=180.0$

Figure 10. Molecular structure of $B_{2}$ ion $c$.<smiles>C[C@@H](NC=O)[C@@H]1OC(=O)[C@@H](C)N1C</smiles>

$$
\begin{aligned}
& r_{12}=1.2888 \\
& r_{13}=1.4571 \\
& r_{43}=1.5147 \\
& r_{54}=1.1538 \\
& r_{61}=0.9996 \\
& r_{72}=1.5044 \\
& r_{17}=1.4328 \\
& r_{92}=1.3524 \\
& r_{109}=1.1996 \\
& r_{199}=1.0834 \\
& r_{123}=0.9959 \\
& r_{133}=1.08717 \\
& r_{143}=1.0808 \\
& r_{157}=1.0833 \\
& r_{167}=1.0836 \\
& r_{172}=1.2919 \\
& r_{174}=1.413792
\end{aligned}
$$

$\mathrm{C}_{3} \mathrm{~N}_{1} \mathrm{C}_{2}=111.091$

$\mathrm{C}_{4} \mathrm{C}_{3} \mathrm{~N}_{1}=100.3125$

$\mathrm{H}_{6} \mathrm{~N}_{1} \mathrm{C}_{3}=124.3342$

$\mathrm{C}_{3} \mathrm{C}_{2} \mathrm{~N}_{1}=126.6239$

$\mathrm{N}_{2} \mathrm{C}_{7} \mathrm{C}_{2}=110.2873$

$\mathrm{C}_{1} \mathrm{~N}_{\mathrm{N}} \mathrm{C}_{7}=117.8318$

$\mathrm{O}_{11} \mathrm{C}_{\mathrm{y}} \mathrm{N}_{\mathrm{x}}=120.4042$

$\mathrm{H}_{11} \mathrm{C}_{3} \mathrm{~N}_{\mathrm{k}}=11.5 .5959$

$\mathrm{H}_{12} \mathrm{~N}_{k} \mathrm{C}_{7}=119.9691$

$\mathrm{H}_{13} \mathrm{C}_{3} \mathrm{~N}_{1}=111.4987$

$\mathrm{H}_{14} \mathrm{C}_{3} \mathrm{~N}_{1}=112.2619$

$\mathrm{H}_{15} \mathrm{C}_{7} \mathrm{C}_{2}=107.1376$

$\mathrm{H}_{16} \mathrm{C}_{1} \mathrm{C}_{2}=108.0971$

$\mathrm{O}_{17} \mathrm{C}_{2} \mathrm{~N}_{1}=113.1987$

Figure 11. Molecular structure of $B_{3}$ ion $d$.

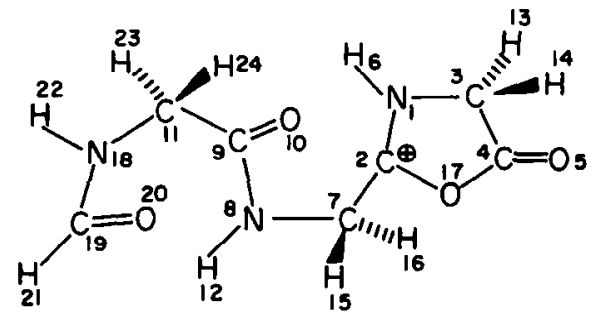

$$
\begin{aligned}
& r_{12}=1.2934 \\
& r_{13}=1.4756 \\
& r_{M}=1.5260 \\
& r_{43}=1.1687 \\
& r_{61}=1.0006 \\
& r_{72}=1.4961 \\
& r_{z y}=1.4466 \\
& r_{91}=1.3600 \\
& r_{109}=1.2242 \\
& r_{119}=1.5194 \\
& I_{\text {Iat }}=1.0108 \\
& r_{133}=1.0796 \\
& r_{143}=1.0804 \\
& r_{197}=1.0827 \\
& r_{167}=1.0806 \\
& r_{12}=1.3138 \\
& r_{174}=1.4520 \\
& r_{1211}=1.4651 \\
& r_{1918}=1.3495 \\
& \mathrm{~T}_{1920}=1.2238 \\
& r_{2119}=1.0786 \\
& r_{2211}=0.9986 \\
& \mathrm{r}_{2331}=1.0766 \\
& r_{2411}=1.0834
\end{aligned}
$$

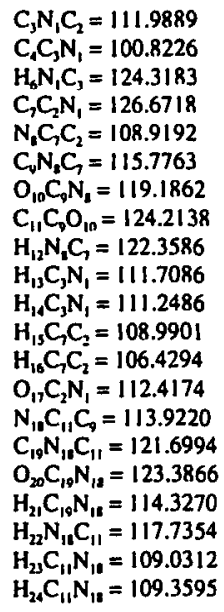

Figure 12. Molecular structure of $\mathrm{B}_{4}$ ion $\mathrm{e}$. 


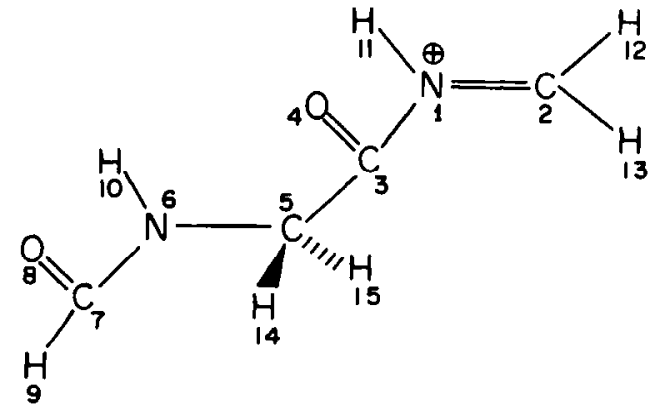

$$
\begin{aligned}
& r_{12}=1.2694 \\
& r_{13}=1.4760 \\
& r_{43}=1.1685 \\
& r_{53}=1.5257 \\
& r_{65}=1.4366 \\
& r_{76}=1.3453 \\
& r_{87}=1.2032 \\
& r_{97}=1.0836 \\
& r_{167}=0.9959 \\
& r_{111}=1.0078 \\
& r_{122}=1.0749 \\
& r_{132}=1.0708 \\
& r_{1+5}=1.0806 \\
& r_{155}=1.0806
\end{aligned}
$$

$C_{3} N_{1} C_{2}=128.9458$

$O_{1} C_{1} N_{1}=114.5936$

$C_{3} C_{3} N_{1}=119.8438$

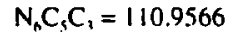

$\mathrm{C}_{7} \mathrm{~N}_{\mathrm{n}} \mathrm{C}_{\mathrm{s}}=118.9289$

$\mathrm{O}_{\mathrm{K}} \mathrm{C}_{7} \mathrm{~N}_{\mathrm{H}}=121.3804$

$\mathrm{H}_{4} \mathrm{C}_{7} \mathrm{~N}_{\mathrm{h}}=115.3571$

$\mathrm{H}_{10} \mathrm{~N}_{\mathrm{n}} \mathrm{C}_{4}=119.9093$

$\mathrm{H}_{11} \mathrm{~N}_{1} \mathrm{C}_{1}=111.3549$

$\mathrm{H}_{12} \mathrm{C}_{2} \mathrm{~N}_{1}=118.7716$

$\mathrm{H}_{12} \mathrm{C}_{2} \mathrm{~N}_{1}=120.6148$

$\mathrm{H}_{14} \mathrm{C}_{5} \mathrm{C}_{1}=111.9687$

$\mathrm{H}_{15} \mathrm{C}_{5} \mathrm{C}_{3}=10.5 .5262$

Figure 13. Molecular structure of immonium ion $\mathrm{f}$.

and energy (Table 4 ) of the $\Lambda_{3}$ ion<smiles>C=[NH+]CC(=O)NC=O</smiles>

formed by elimination of $\mathrm{CO}$ from the $\mathrm{B}_{3}$ ion. The results show that the products $\mathrm{A}_{3}+\mathrm{CO}$ are $0.8 \mathrm{eV}$ higher in energy than the protonated oxazolone, consistent with the calculations reported earlier [7] for the $B_{2} \rightarrow A_{2}+C O$ reaction. However, we are unable to obtain a reliable calculated energy for the acyclic

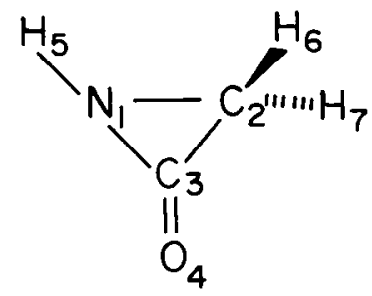

$$
\begin{aligned}
& r_{12}=1.5119 \\
& r_{13}=1.3440 \\
& r_{23}=1.4890 \\
& r_{43}=1.1935 \\
& r_{51}=0.9972 \\
& r_{62}=1.0741 \\
& r_{72}=1.0699
\end{aligned}
$$

$\mathrm{C}_{1} \mathrm{C}_{2} \mathrm{~N}_{1}=53.2074$

$\mathrm{O}_{4} \mathrm{C}_{1} \mathrm{~N}_{1}=143.8325$

$\mathrm{H}_{4} \mathrm{~N}_{1} \mathrm{C}_{2}=133.3384$

$\mathrm{H}_{\mathrm{h}} \mathrm{C}_{2} \mathrm{~N}_{1}=118.2898$

$\mathrm{H}_{7} \mathrm{C}_{2} \mathrm{~N}_{1}=114.9512$

Figure 14. Molecular structure of $\alpha$-lactam $\mathbf{g}$.

Table 4. Total calculated energies

\begin{tabular}{llc}
\hline & \multicolumn{2}{c}{ Energy (hartree) } \\
\cline { 2 - 3 } Species $^{a}$ & $H F / 3-21 G$ & $H F / 6-31 G^{b}$ \\
\hline \hline $\mathbf{c}\left(B_{2}\right)$ & -318.064769 & -319.860295 \\
$d\left(B_{3}\right)$ & -523.744520 & -526.693741 \\
$e\left(B_{4}\right)$ & -729.416197 & \\
$f\left(A_{3}\right)$ & -411.614720 & -413.927133 \\
$g$ & -205.549728 & -206.726115 \\
CO $^{b}$ & -112.093299 & -112.737877 \\
\hline
\end{tabular}

${ }^{\mathrm{B}} \mathrm{C}=\mathrm{B}_{2}$ protonated oxazolone (cf. Figure 10 ); $\mathbf{d}=\mathrm{B}_{3}$ protonated oxazolone (cf. Figure 11); $\mathbf{e}=\mathbf{B}_{4}$ protonated oxazolone (cf. Figure 12); $f=$ immonium ion $\left(A_{3}\right)$ (cf. Figure 13 ) $g=\alpha$-lactam (cf. Figure 14).

${ }^{b}$ For CO data, see ref 7

acylium ion that is presumably a transient intermediate in the fragmentation of the stable $B_{3}$ ion to the $\mathrm{A}_{3}$ ion.

An interesting experimental observation is that the larger $B_{n}$ ions $(n \geq 3)$ fragment, in part, to the nextlower $\mathrm{B}$ ion $\left(\mathrm{B}_{n-1}\right)$. As indicated by the data in Tables 2 and 3 , this reaction occurs with a relatively low kinetic energy release. The calculated stable structures for the $B_{3}$ and $B_{4}$ ions (Figures 11 and 12) show that the next-nearest carbonyl oxygen is close to the charge site in the oxazolone ring. This is shown more clearly in the three-dimensional representation of the $B_{3}$ ion presented in Figure 15. Thus, as shown in Scheme IV, fragmentation by reaction 3 , which forms the nextlower B ion in the stable oxazolone structure, should occur reasonably readily. The minimum found theoretically for the neutral fragment in reaction 3 was the cyclic $\alpha$-lactam or aziridinone depicted in Figure 14 . Such $\alpha$-lactams have been shown [21] to be formed when protonated peptides fragment to form $Y$ ions by elimination of the $N$-terminus amino acid residue. The calculated total energies given in Table 4 indicate that, for our model system, the $\left(B_{2}+\alpha\right.$-lactam) products are $2.7 \mathrm{eV}$ higher in energy than the precursor $B_{3}$ ion, which suggests, in this case, a critical reaction energy for reaction 3 that is considerably higher than that for<smiles>[R]C(=O)NC([R])C(=O)NC([R])C([R])=O</smiles><smiles>[R]C(=O)NC([R])[C+]1NC([R])C(=O)O1</smiles>

Scheme III 


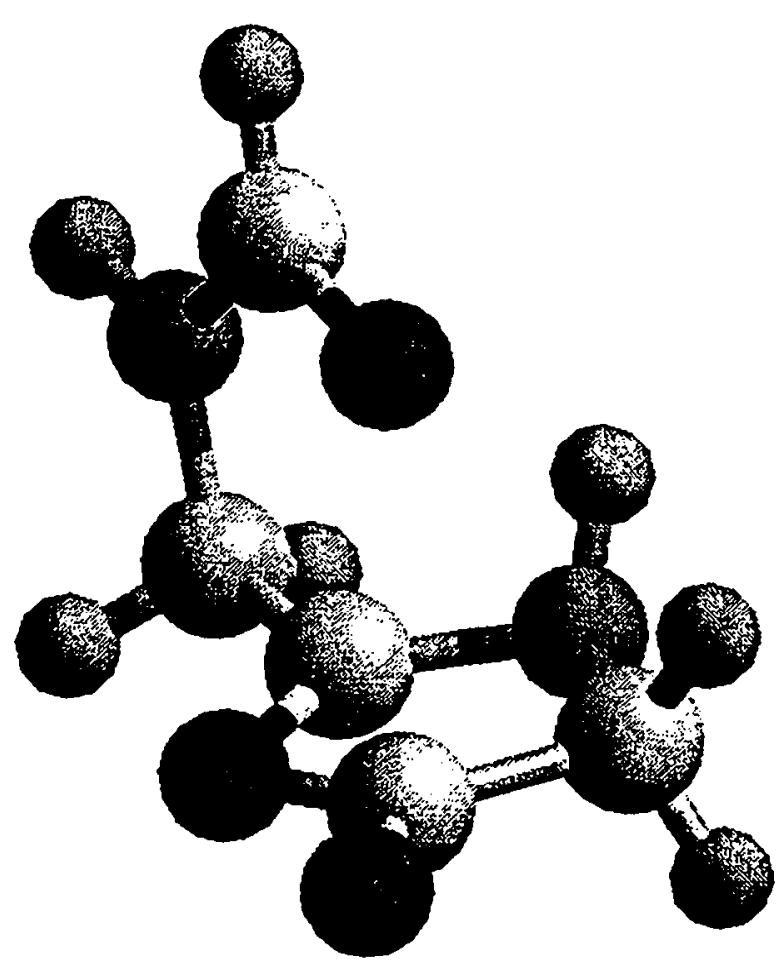

Figure 15. Three-dimensional structure of the $B_{3}$ ion.

reaction 2. However, the relative importance of reactions 2 and 3 will depend strongly on the identities of the amino acid residues in the $B_{n}$ precursor ion. We note, for example, that the $B_{3}$ ion derived from Leu-enkephalin fragments predominantly to form the $B_{2}$ ion (Figure 9) whereas the $B_{4}$ ion fragments (Figure 10) predominantly by elimination of $\mathrm{CO}$ to form the $\mathrm{A}_{4}$ ion (reaction 2).

A referee has raised the possibility that because peptides are known to produce oxazolones in solution, our apparent observation of oxazolone structures may reflect prior formation of these species in the $\mathrm{FAB}$ matrix with subsequent ionization of these preformed oxazolones. To test for this possibility we have carried out a limited comparison of the fragmentation of $B$ ions produced by $F A B$ with the same nominal $B$ ion produced in the gas phase by $\mathrm{CH}_{4}$ chemical ionization.

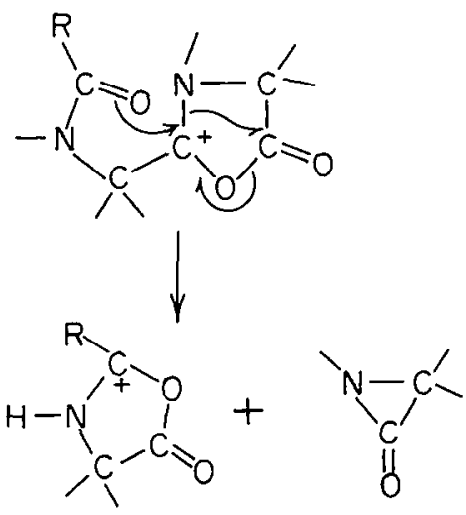

Scheme IV
The comparison was limited because it was impossible to obtain $\mathrm{CH}_{4} \mathrm{CI}$ mass spectra for most of the peptides studied in the present work. Figure 16 compares the 45-eV CID mass spectra of the $B_{3}$ ion derived from Ac-(Ala) ${ }_{3}$-OMe by $\mathrm{FAB}$ and by $\mathrm{CH}_{4} \mathrm{CI}$, whereas Figure 17 compares the $45-\mathrm{eV}$ CID mass spectrum for the $\mathrm{B}_{4}$ ion derived from Ac-(Ala) ${ }_{3}-\mathrm{OMe}$ by $\mathrm{CH}_{4} \mathrm{CI}$ with the CID spectra of the same nominal ion derived from Ac-(Ala) ${ }_{3}$-OMe and Ac-(Ala) $)_{4}$-OMe by FAB. The good agreement of the CID spectra for the $B$ ions produced in the gas phase by $\mathrm{CH}_{4} \mathrm{CI}$ with the $\mathrm{CID}$ spectra of the $B$ ions observed in the FAB mass spectra provides substantial evidence that we are not preforming oxazolones in the FAB matrix and ionizing these preformed species. It is much more likely that the $B$ ions observed in the $F A B$ mass spectra originate by fragmentation of $\mathrm{MH}^{+}$ions in the gas phase.

However, we note that caution must be exercised in interpretation of the results obtained for fragmentation of ions produced by gas phase chemical ionization. The top panel of Figure 18 shows the metastable ion spectrum of protonated cyclo-Leu-Gly $(\mathrm{m} / \mathrm{z} 171)$ produced by $\mathrm{CH}_{4} \mathrm{Cl}$. The spectrum is in good agreement with that recorded for protonated cyclo-Leu-Gly produced by FAB (Figure 5, ref 7). The middle panel of Figure 18 shows the metastable ion spectrum of the $m / z 171\left(\mathrm{~B}_{2}\right)$ ion observed in the $\mathrm{CH}_{4} \mathrm{CI}$ mass spectrum of H-Leu-Gly- $\mathrm{NH}_{2}$ when the peptide was introduced into the source by way of a conventional heated solids probe. The agreement of the spectrum observed in this case with that of protonated cyclo-Leu-Gly
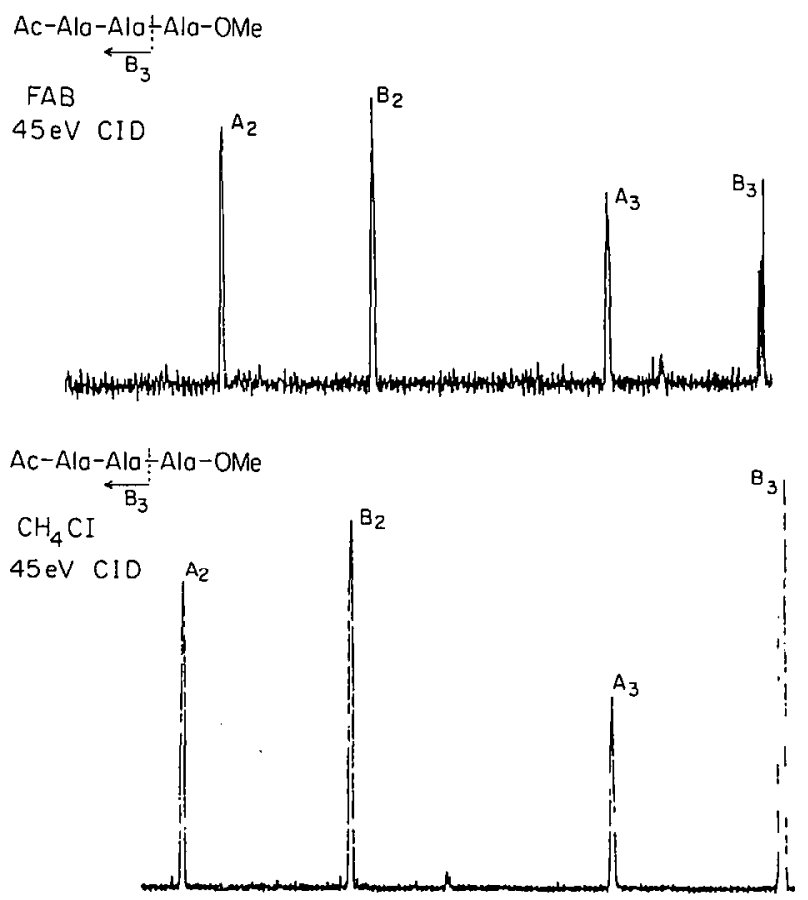

Figure 16. $C I D$ mass spectrum $(45 \mathrm{eV})$ of the $B_{3}$ ion observed in the $\mathrm{FAB}$ mass spectrum (top) and the $\mathrm{CH}_{4} \mathrm{CI}$ mass spectrum (bottom) of Ac-(Ala) ${ }_{3}-\mathrm{OMe}$. Sample introduced by heated solids probe in the $\mathrm{CI}$ experiment. 


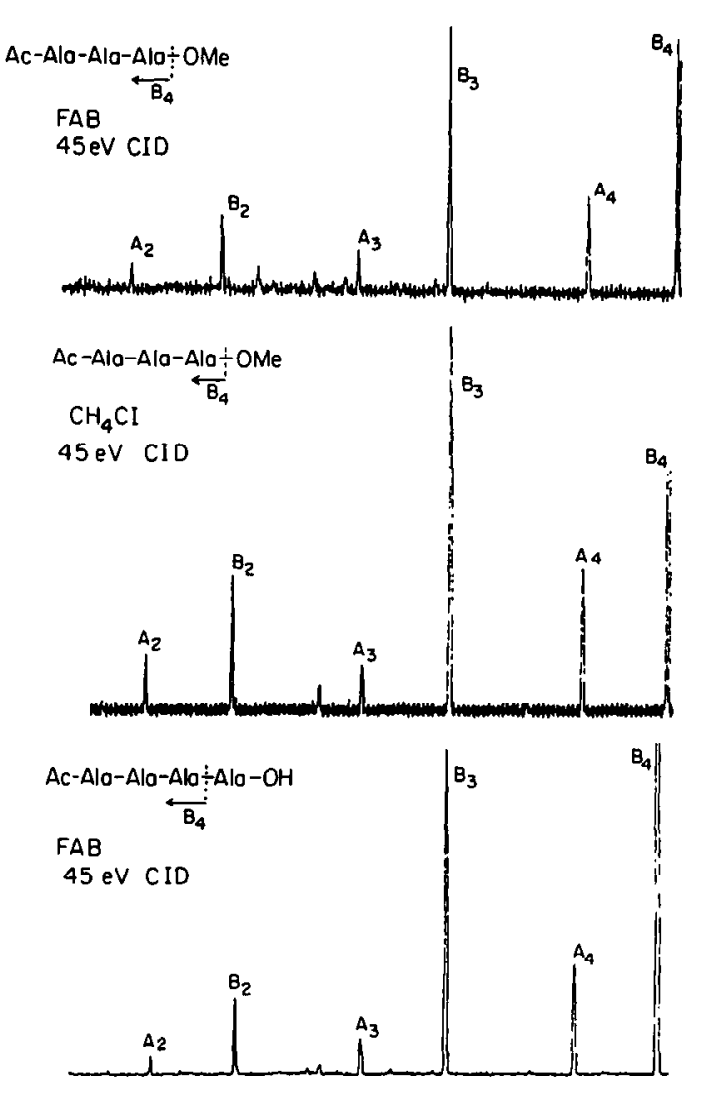

Figure 17. CID mass spectrum ( $45 \mathrm{eV})$ of the $B_{4}$ ion observed in the $\mathrm{FAB}$ mass spectrum (top) and the $\mathrm{CH}_{4} \mathrm{CI}$ mass spectrum (middle) of Ac-(Ala) $)_{3}$-OMe. (Bottom) 45-eV CID mass spectrum of the $\mathrm{B}_{4}$ ion observed in the FAB mass spectrum of Ac- (Ala $)_{4}-\mathrm{OH}$. In the $\mathrm{CI}$ experiment the sample was introduced by heated solids probe.

leaves little doubt that the $m / z 171$ ion we studied has the diketopiperazine structure. However, when we introduce the peptide into the ion source by way of the direct exposure probe, without heating of the probe, we observe (bottom panel, Figure 18) a much different metastable ion spectrum, which is in essential agreement with that recorded (Figure 5, ref 7) for the $m / z$ 171 ion observed in the FAB mass spectra of H-LeuGly-Gly-OH and H-Leu-Gly- $\mathrm{NH}_{2}$. Clearly, the attempt to introduce $\mathrm{H}$-Leu-Gly- $\mathrm{NH}_{2}$ into the $\mathrm{CI}$ source by way of the heated solids probe has led to decomposition of the peptide on the probe to form the diketopiperazine cyclo-Leu-Gly, which subsequently is ionized by $\mathrm{CH}_{4} \mathrm{Cl}$.

\section{Conclusions}

The essential conclusions of the present work are that the $B_{3}$ and $B_{4}$ ions observed as stable species in peptide mass spectra are not acyclic acylium ions but have rearranged to more stable structures during formation. All the experimental and theoretical evidence suggests that these structures are protonated substituted oxazolones formed by interaction of the developing charge with the next-adjacent carbonyl group as HX is lost
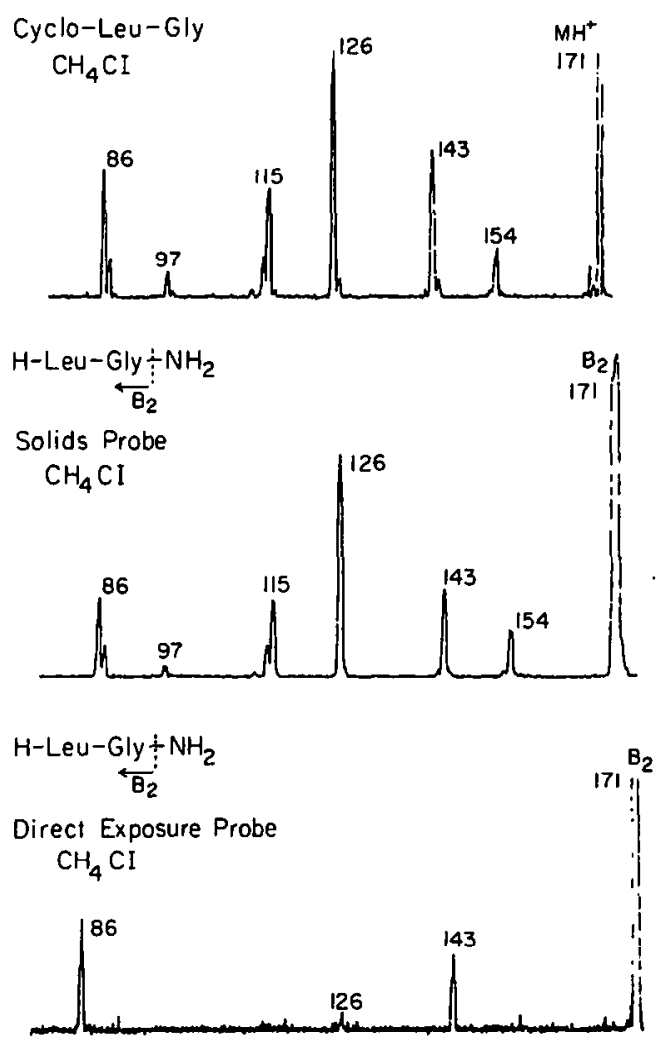

Figure 18. Unimolecular fragmentation spectrum of the $m / z$ 171 ion observed in the $\mathrm{CH}_{4} \mathrm{CI}$ mass spectrum of cyclo-Leu-Gly (top), H-Leu-Gly- $\mathrm{NH}_{2}$ with sample introduced by heated solids probe (middle), and $\mathrm{H}$-Leu-Gly- $\mathrm{NH}_{2}$ with sample introduced by unheated direct exposure probe (bottom).

from the protonated species $\mathrm{H}-(\mathrm{Yyy})_{n}-\mathrm{X} \cdot \mathrm{H}^{+}$. However, we have not been able to prepare the oxazolone structures by an independent route for comparison, so there must remain a slight uncertainty in our conclusions. Nevertheless, we believe that the $B_{3}$ and $B_{4}$ ions most likely have the same cyclic structure as the $B_{2}$ ions [7]. We anticipate that larger $B_{n}$ ions also will have the protonated oxazolone structure.

The protonated oxazolones fragment, in part, by ring opening to form a transient acyclic acylium ion that exothermically eliminates $\mathrm{CO}$ to form an $\mathrm{A}$ ion. A considerable part of this exothermicity is released as kinetic energy of the separating fragments that leads to $T_{1 / 2}$ values in the range $0.3-0.5 \mathrm{eV}$. An alternative fragmentation channel for the larger $\mathrm{B}_{n}(n \geq 3)$ ions is fragmentation to the next-lower $B$ ion by elimination of the $C$-terminus amino acid residue as an $\alpha$-lactam (Scheme IV).

Finally, the present work and our earlier study [7] clearly show that the fragmentation behavior of an $\mathrm{N}$-acyl peptide is very similar to that of a peptide that contains one additional amino acid residue. That is, the addition of an acyl group to the $N$-terminus of a peptide has much the same effect as adding an amino acid to the $\mathrm{N}$-terminus. Thus, the fragmentation behavior of protonated $\mathrm{N}$-acetyl tri-alanine (Figure 2) is very similar to that of protonated tetra-alanine 
(Figure 3) and the fragmentation of protonated $\mathrm{N}$ acetyl tetra-alanine (Figure 4) is very similar to that of protonated penta-alanine (Figure 5). It is for this reason that we have chosen, in the present article, to designate $B$ ions $\left(B_{2}, B_{3}, B_{4}\right.$, etc.) in terms of the number of carbonyl groups present rather than in terms of the number of amino acid residues contained in the ion.

\section{Acknowledgments}

The authors are indebted to the Natural Sciences and Engineering Research Council (Canada) for financial support and to VG Analytical for the loan of the fast-atom gun and FAB source.

\section{References}

1. Milne, G. W. A.; Axenrod, T.; Fales, H. M. J. Am. Chem. Soc $1970,92,5170$.

2. LeClerq, P. M.; Desiderio, D. M. Org. Mass Spectrom. 1973, 7, 515.

3. Tsang, C. W.; Harrison, A. G. J. Am. Chem. Soc. 1976, 98, 1301.

4. Kulik, W.; Heerma, W. Biomed. Environ. Mass Spectrom. 1988, 15, 419.

5. Buchonnet, S.; Denhez, J. P.; Hoppilliard, Y.; Mauriac, C. Anal. Chem. 1992, 64, 743.

6. Bouchoux, G.; Bourcier, S.; Hoppilliard, Y.; Mauriac, C. Org. Mass Spectrom. 1993, 28, 1064.

7. Yalcin, T.; Khouw, C.; Csizmadia, I. G.; Peterson, M. R.; Harrison, A. G. J. Am. Soc. Mass Spectrom. 1995, 6, 1165.

8. Roepstorff, P.; Fohlman, J. Biomed. Mass Spectrom. 1984, 11, 601.
9. Hunt, D. F.; Yates, J. R., III; Shabanowitz, J.; Winston, S.; Hauer, C. R. Proc. Natl. Acad. Sci., USA 1986, 83, 6233.

10. Biemann, K.; Martin, S. Mass Spectrom. Rev. 1987, 6, 75.

11. Biemann, K. Biomed. Environ. Mass Spectrom. 1988, 16, 99.

12. Biemann, K. In Mass Spectrometry. Methods in Enzymology; McCloskey, J. A., Ed.; Academic Press: San Diego, 1990; Vol. 193, Chaps. 18, 25.

13. Biemann, K. In Biological Mass Spectrometry Present and Future; Matsuo, T.; Caprioli, R. M.; Gross, M. L.; Seyama, T., Eds.; Wiley: New York, 1993.

14. Holmes, J. L.; Terlouw, J. K. Org. Mass Spectrom. 1980, 15 , 383.

15. Harrison, A. G.; Mercer, R. S.; Reiner, E. J.; Young, A. B.; Boyd, R. K.; March, R. E.; Porter, C. J. Int. I. Mass Spectrom. Ion Processes 1986, 76, 13.

16. Cooks, R. G.; Beynon, J. H.; Caprioli, R. M.; Lester, G. R. Metastable Ions; Elsevier: New York, 1973.

17. Alexander, A. J.; Boyd, R. K. Int. J. Mass Spectrom. Ion Processes 1989, 90, 211.

18. Cheng, X.; Wu, Z.; Fenselau, C.; Ishihara, M.; Musselman, B. D. J. Am. Soc. Mass Spectrom. 1995, 6, 175.

19. Frisch, M. J.; Trucks, G. W.; Head-Gordon, M.; Gill, P. M. W.; Wong, M. W.; Foresman, J. B.; Johnson, B. G.; Schlegel, H. B.; Robb, M. A.; Replogle, E. S.; Gomperts, R.; Andres, J. A.; Raghavachari, K.; Binkley, J. S.; Gonzalez, C.; Martin, R. L.; Fox, D. J.; Defrees, D. J.; Baker, J.; Stewart, J. J. P.; Pople, J. A. Gaussian 92; Gaussian: Pittsburgh, PA, 1992.

20. Binkley, J. S.; Pople, J. A.; Hehre, W. J. J. Am. Chem. Soc. 1980, 102, 939.

21. Cordero, M. M.; Houser, J. J.; Wesdemiotis, C. Anal. Chem. 1993, 65, 1594. 